\title{
Calcitonin gene related peptide immunoreactivity in rat lung: light and electron microscopic study
}

\author{
JOSEPH M LAUWERYNS, LIEVE VAN RANST \\ From the Laboratory of Histopathology, Faculty of Medicine, Catholic University of Leuven, Belgium
}

ABSTRACT Calcitonin gene related peptide immunoreactivity was investigated in the rat lung. Immunoreactive material was observed in nerve fibres surrounding bronchi, bronchioli, and blood vessels, and also in neuroendocrine cells and neuroepithelial bodies. In addition, the peptide was identified by immunoelectron microscopy in dense cored vesicles of granulated cells of the neuroepithelial bodies. These observations suggest that calcitonin gene related peptide plays a part in the regulatory function of the rat respiratory tract, exerting its influence by endocrine, paracrine, neurosecretory pathways, or a combination of these.

Calcitonin gene related peptide (CGRP) is a peptide of 37 amino acids encoded on the calcitonin gene. ${ }^{1}$ It depends for its expression on specific RNA processing, which gives rise to a messenger RNA different from the mRNA for calcitonin. ${ }^{2}$ It is found in thyroid parafollicular cells and in nuclei and nerve fibres of the central and peripheral nervous systems, ${ }^{13-9}$ and may act as an extracellular modulator. ${ }^{9}$ Human CGRP differs from rat CGRP in four positions of its amino acid sequence. ${ }^{10} \mathrm{~A}$ second calcitonin-CGRP gene has recently been identified in rat and human tissue. ${ }^{1112}$ In the rat this gene produces a CGRP like peptide differing from the originally analysed CGRP by only one amino acid.

The respiratory mucosa of several mammalian species contains cells of the APUD series, occurring either as single neuroendocrine cells or in corpuscular aggregates - the neuroepithelial bodies. ${ }^{13-15}$ Since calcitonin has been identified in rat neuroendocrine cells and neuroepithelial bodies, ${ }^{16}$ we undertook an investigation to find out whether CGRP is also present in these structures.

\section{Methods}

\section{TISSUE PREPARATION}

Seven Wistar rats aged 12-14 days were anaesthetised with an intraperitoneal injection of pentobarbitone sodium $(35 \mathrm{mg} / \mathrm{kg})$. For light microscopy the lungs of

Address for reprint requests: Professor Dr JM Lauweryns, Koning Leopold III laan 47, B-3030 Heverlee-Leuven, Belgium.

Accepted 24 September 1986 three rats were fixed in situ by a gentle intratracheal instillation of $10 \%$ neutral formalin until they were expanded in the opened thoracic cage. Subsequently the divided lung lobes were immersed in the same fixative for 6-24 hours. Air was removed by brief exposure to vacuum. Half of the material from each rat was embedded in paraffin wax. Sections $5 \mu \mathrm{m}$ thick were cut and dried overnight at $37^{\circ} \mathrm{C}$, dewaxed, and brought through graded alcohols to water. The remaining material was rinsed in $0.1 \mathrm{~mol} / 1$ phosphate buffer containing $5 \%$ sucrose and snap frozen. Cryostat sections $3 \mu \mathrm{m}$ thick were picked up on chrome alum-gelatin coated slides and allowed to dry at room temperature for between 30 minutes and three hours.

The lungs of the other four rats were fixed with $4 \%$ paraformaldehyde, $0.3 \%$ glutaraldehyde, and $0.2 \%$ picric acid in $0.1 \mathrm{~mol} / 1$ phosphate buffer $(\mathrm{pH} 7 \cdot 3)$ as described above, cut into small pieces, and left in the same fixative for two to three hours. Five samples from each animal were also postfixed in osmic acid for one hour. All samples, whether osmicated or nonosmicated, were embedded in Dow epoxy resin. Survey sections $1 \mu \mathrm{m}$ thick were stained with toluidine blue, and when a neuroepithelial body was found the block was trimmed. Ultrathin sections were collected on cleaned, uncoated gold grids and dried overnight.

\section{ANTISERA}

Commercial antisera against synthetic human CGRP (Amersham) and synthetic rat CGRP (Cambridge Research Biochemicals) were used. Both antisera were raised in rabbits, and had previously been characterised by absorption with purified CGRP, calcitonin, substance $\mathrm{P}$ and galanin $(2 \mathrm{nmol} / \mathrm{ml}$ 
diluted antiserum). Immunoreactivity was abolished by pure CGRP but not by calcitonin, substance $P$, or galanin.

PEROXIDASE-ANTIPEROXIDASE METHOD

Endogenous peroxidase in the paraffin sections was blocked by a fresh $0.5 \%$ solution of hydrogen peroxide in methanol for 15 minutes and in cryostat sections by $0.3 \%$ of hydrogen peroxide in tris buffered saline (TBS) at $\mathrm{pH} 7.6$ for 30 minutes. The sections were then rinsed with TBS. (All rinses and serum dilutions were made with this buffer unless indicated otherwise.) Sections were then exposed to normal swine serum, diluted 1:5, for 45 minutes at room temperature; excess serum was removed without rinsing. The sections were next treated with rabbit anti-CGRP at a dilution of 1:400 for 20 hours at $4^{\circ} \mathrm{C}$. After thorough rinsing, unlabelled swine antirabbit IgG, diluted 1:20, was applied for 30 minutes at room temperature. The sections were rinsed and treated with rabbit antiperoxidase-peroxidase complex diluted 1:50 for 30 minutes at room temperature. After a final washing the end product was detected with a fresh solution of $0.02 \% 3,3$-diaminobenzidine tetrahydrochloride (DAB) in $0.1 \mathrm{~mol} / \mathrm{l}$ tris buffer (pH 7.6) containing $0.01 \%$ hydrogen peroxide for five minutes at room temperature. The sections were dehydrated, cleared in toluene, and mounted in DPX.

Controls included non-immune rabbit serum used instead of the anti-CGRP serum, and CGRP antiserum preabsorbed with pure synthetic CGRP ( $2 \mathrm{nmol} / \mathrm{ml}$ diluted antiserum).

\section{IMMUNOGOLD STAINING METHOD FOR}

ELECTRON MICROSCOPY

For the immunogold staining method for electron microscopy, ${ }^{17}$ ultrathin sections of the nonosmicated tissue were etched in $10 \%$ hydrogen peroxide solution for 10 minutes at room temperature. Sections of osmicated tissue were treated with a saturated aqueous solution of sodium metaperiodate for 30-60 minutes at room temperature to enhance immunoreactivity. ${ }^{18}$ After thorough washing in distilled water, the grids were placed in droplets of normal goat serum diluted 1:30 in PBS containing $0.1 \%$ bovine serum albumin ( $\mathrm{pH} \mathrm{7.2)} \mathrm{for} 45$ minutes at room temperature. Excess goat serum was drained off and the grids were incubated in droplets of rabbit anti-CGRP diluted 1:800 in PBS for 20 hours at $4^{\circ} \mathrm{C}$. After thorough rinsing in $50 \mathrm{mmol} / \mathrm{l}$ tris buffer (pH 7.2) and $50 \mathrm{mmol} / \mathrm{l}$ tris buffer containing $0.2 \%$ bovine serum albumin $(\mathrm{pH} 7 \cdot 2)$ the grids were placed in droplets of $50 \mathrm{mmol} / \mathrm{l}$ tris buffer containing $1 \%$ bovine serum albumin ( $\mathrm{pH} 8.2)$ for five minutes. Subsequently the grids were placed in droplets of $10 \mathrm{~nm} \cdot$ gold labelled goat antirabbit IgG (Janssen
Pharmaceutica, Beerse, Belgium) for one hour at room temperature. The gold sol was diluted, after centrifugation, with tris $-1 \%$ bovine serum albumin buffer (pH 8.2). The grids were washed in copious vol- $\frac{}{\bar{N}}$ umes of tris $-0.2 \%$ bovine serum albumin buffer, tris

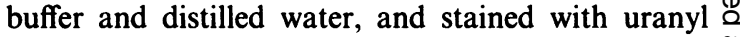
acetate and lead citrate.

Control sections were prepared by using nonimmune rabbit serum as the first layer and by applying CGRP antiserum preabsorbed with pure $\vec{\omega}$ synthetic CGRP $(2 \mathrm{nmol} / \mathrm{ml}$ diluted serum).

\section{Results}

PEROXIDASE-ANTIPEROXIDASE METHOD

On cryostat sections CGRP immunoreactivity was observed in the lungs of all animals studied. Numerous immunoreactive nerve fibres were distributed around bronchi and bronchioli (figs 1-4), terminating $\frac{3}{工}$ close to the epithelial basement membrane and $\vec{\bullet}$ sometimes forming varicosities (fig 4). Beneath the $\infty$ epithelium occasional structures containing a heavy black precipitate were observed, probably corresponding to small ganglia (fig $5 a$ ). Some immunoreactive nerve fibres were also seen around blood vessels. Immunoreactive nerve fibres were not detected in paraffin sections.

CGRP immunoreactivity was also found in neuroepithelial bodies (figs $5 a$ and $5 b$ ) and neuroendocrine cells (fig $5 b$ ) in both cryostat and paraffin sections. Neuroendocrine cells and neuroepithelial bodies were present throughout the airways and alveoli of all the animals studied, displaying a strong granular cytoplasmic staining pattern with both antisera, and were easily distinguished from other non-reactive cells of the bronchiolar and alveolar epithelium. Neuroendocrine cells were mostly pyramidal and situated close to the basement membrane. Morphologically, neuroepithelial bodies were characteristically nodular, with more pronounced immunoreactivity in $\frac{D}{O}$ the basal part of the cytoplasm (fig 5a). The intensity and localisation of the immunoreactivity in nerves, $N$ neuroendocrine cells, and neuroepithelial bodies were similar with the two antisera. No immunoreactivity was observed in the control sections.

\section{ULTRASTRUCTURAL OBSERVATIONS}

The morphology of the rat neuroepithelial body has $\stackrel{\circ}{\rightarrow}$ been determined in earlier studies. ${ }^{14}{ }^{15}$ In routinely 0 processed material fixed in glutaraldehyde and osmic $\stackrel{+}{P}$ acid dense cored vesicles are seen, mainly in the basal $\stackrel{\mathbb{\Omega}}{\mathbb{Q}}$

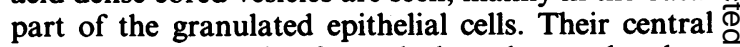
cores vary in density from dark and granulated to pale and moderately electron dense (fig 6). 


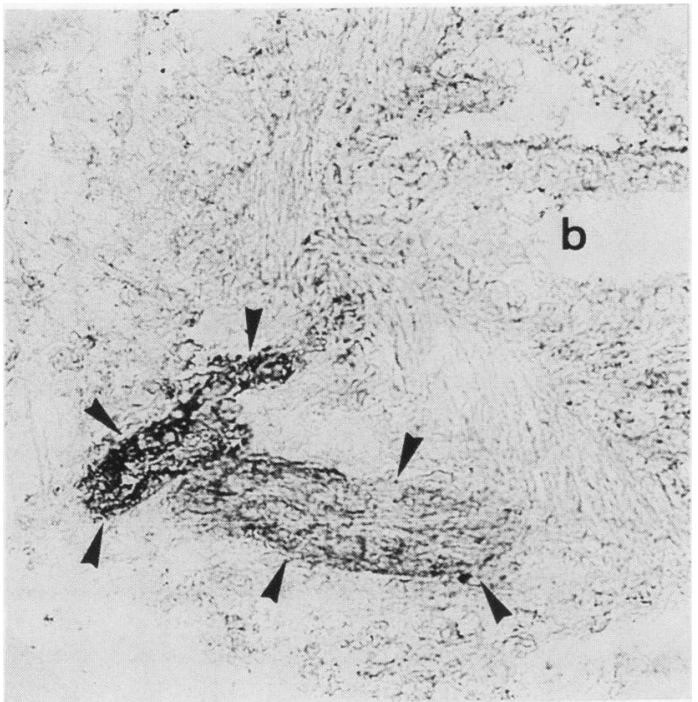

Fig 1

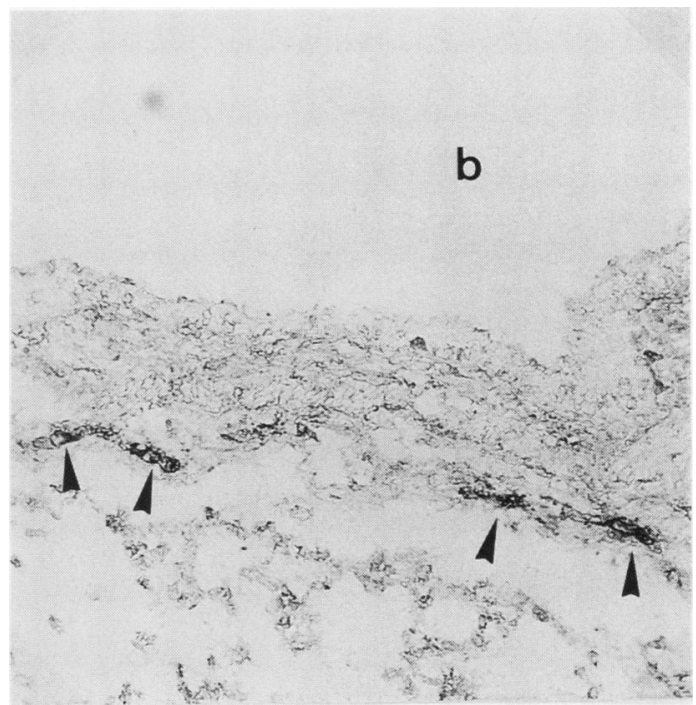

Fig 2
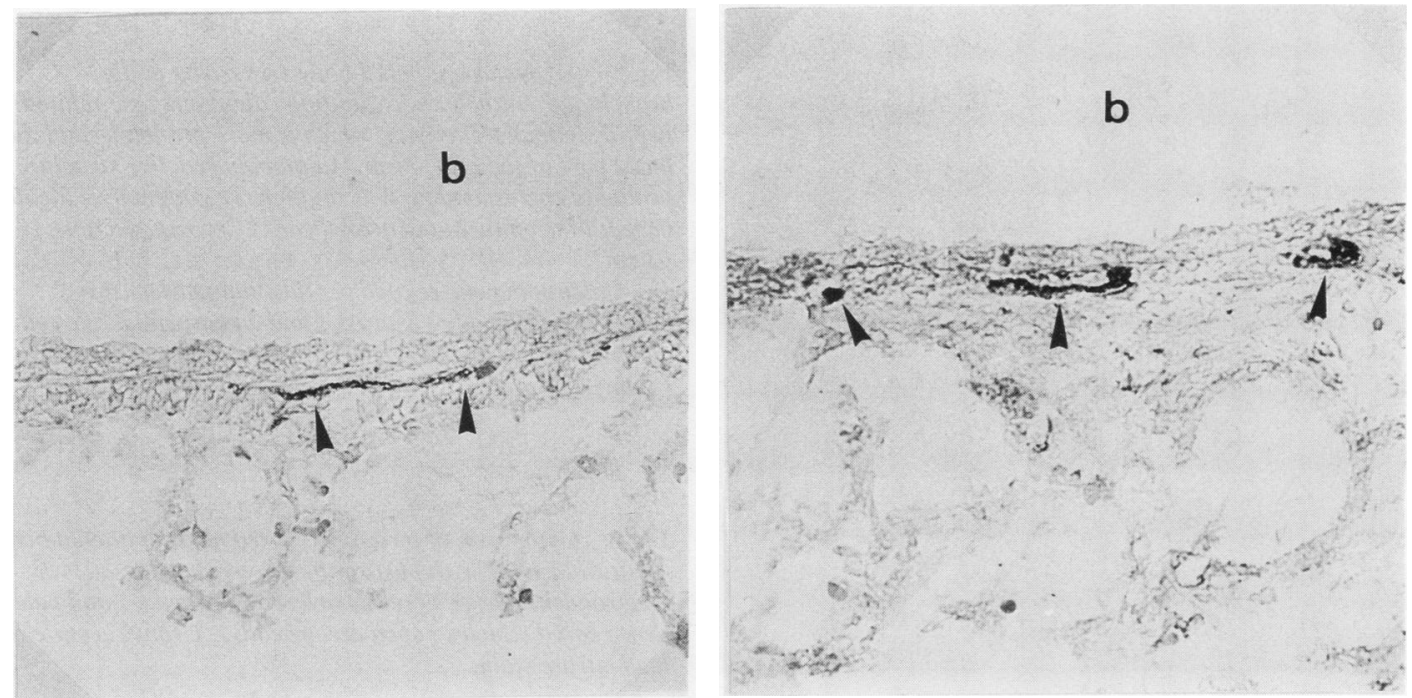

Fig 3

Fig 4

Fig 1 Large bundle of calcitonin gene related peptide immunoreactive nerve fibres (arrowheads) surrounding a large bronchiole (b). Cryostat section $(3 \mu \mathrm{m})$.

Fig 2 Calcitonin gene related peptide immunoreactive nerve fibres (arrowheads) surrounding a bronchiole (b). Cryostat section $(3 \mu \mathrm{m})$.

Fig 3 Calcitonin gene related peptide immunoreactive nerve fibre(s) (arrowheads) beneath the epithelium of a bronchiole (b). Cryostat section $(3 \mu \mathrm{m})$.

Fig 4 Calcitonin gene related peptide immunoreactive nerve fibres (arrowheads) forming local varicosities beneath the epithelium of a bronchiole (b). Cryostat section ( $3 \mu \mathrm{m})$. 


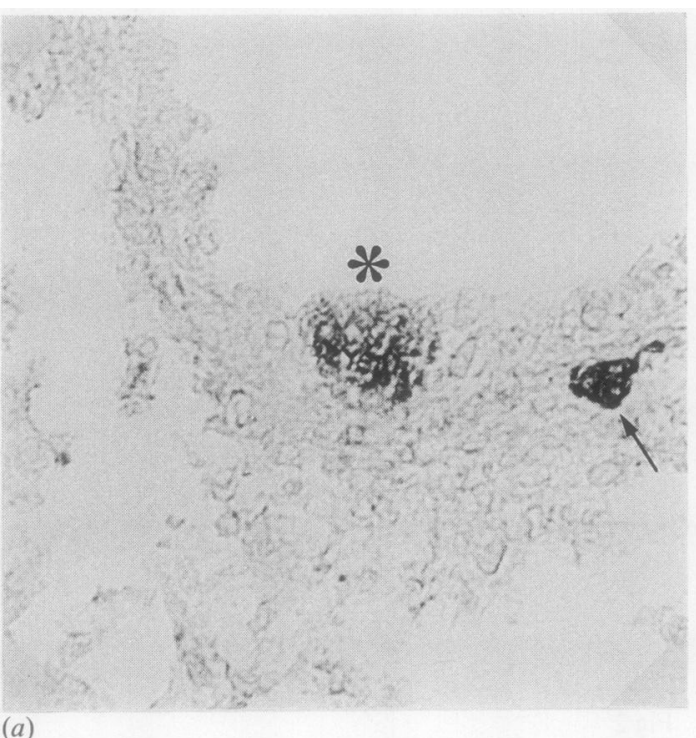

(a)

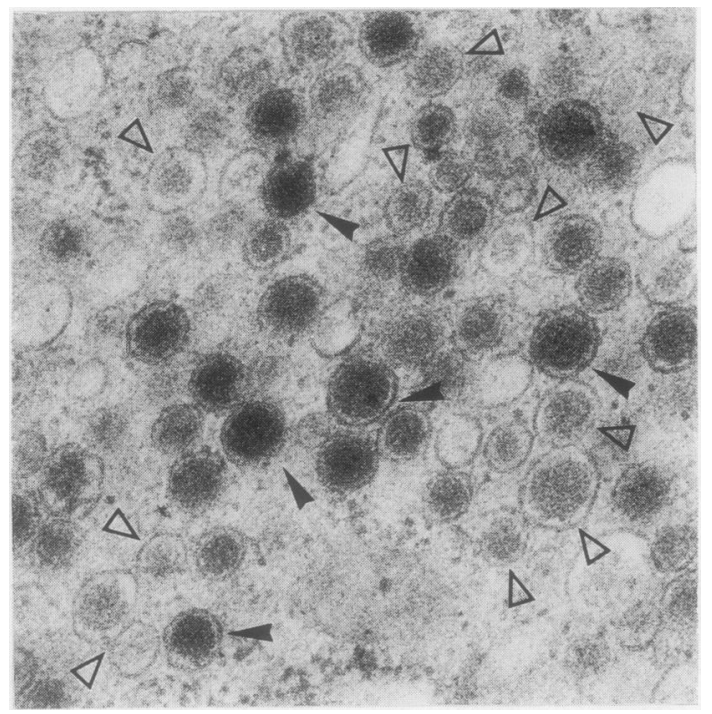

IMMUNOGOLD STAINING

Immunogold staining applied to the non-osmicated tissue revealed distinct CGRP immunoreactivity, with deposition of $10 \mathrm{~nm}$ gold particles, over dense cored vesicles of variable core density (figs 7 and 8). Because osmification was omitted, the membranes were poorly preserved, making the distinction between pale dense cored vesicles and cytoplasm less obvious in some areas (fig 8). Nevertheless the gold labelling over these less electron dense cored vesicles could still be differentiated from the non-specific, scattered deposit of gold particles in the adjacent cytoplasm. CGRP immunoreactivity was restricted to

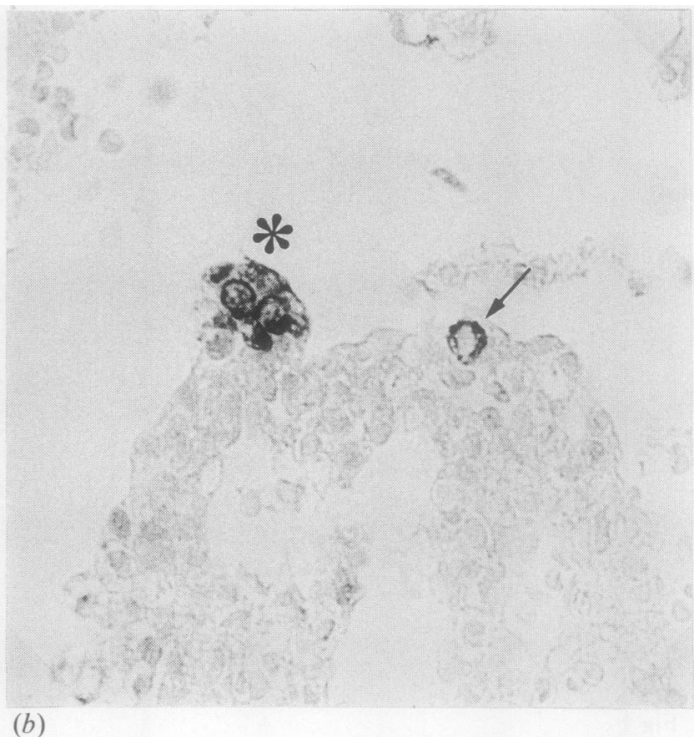

Fig 5 (a) Neuroepithelial body (asterisk) in the bronchiolar epithelium, exhibiting calcitonin gene related peptide immunoreactivity, which is more pronounced in the basal part of the cytoplasm. An immunoreactive structure, probably corresponding to a small nerve ganglion, is located beneath the epithelium (arrowhead). Cryostat section $(3 \mu \mathrm{m})$.

(b) Calcitonin gene related peptide immunoreactive neuroepithelial body (asterisk) and a neuroendocrine cell (arrow) within the alveolar epithelium. Paraffin section $(5 \mu \mathrm{m})$.

Fig 6 Cytoplasm of a routinely fixed neuroepithelial body (glutaraldehyde with postosmification) showing electrondense dense cored vesicles (arrowheads) and pale dense cored vesicles (open arrowheads). Uranyl acetate and lead citrate stain.

the dense cored vesicles. No specific labelling was observed in nerve endings (fig 7), although some non ${ }^{0}$ specific deposit was occasionally seen over mitochondria.

Immunogold staining applied to the sections of osmicated tissue did not result in any gold labelling.

No immunoreactivity was observed in the controps sections.

\section{Discussion}

This study shows that in the young rat immunor 


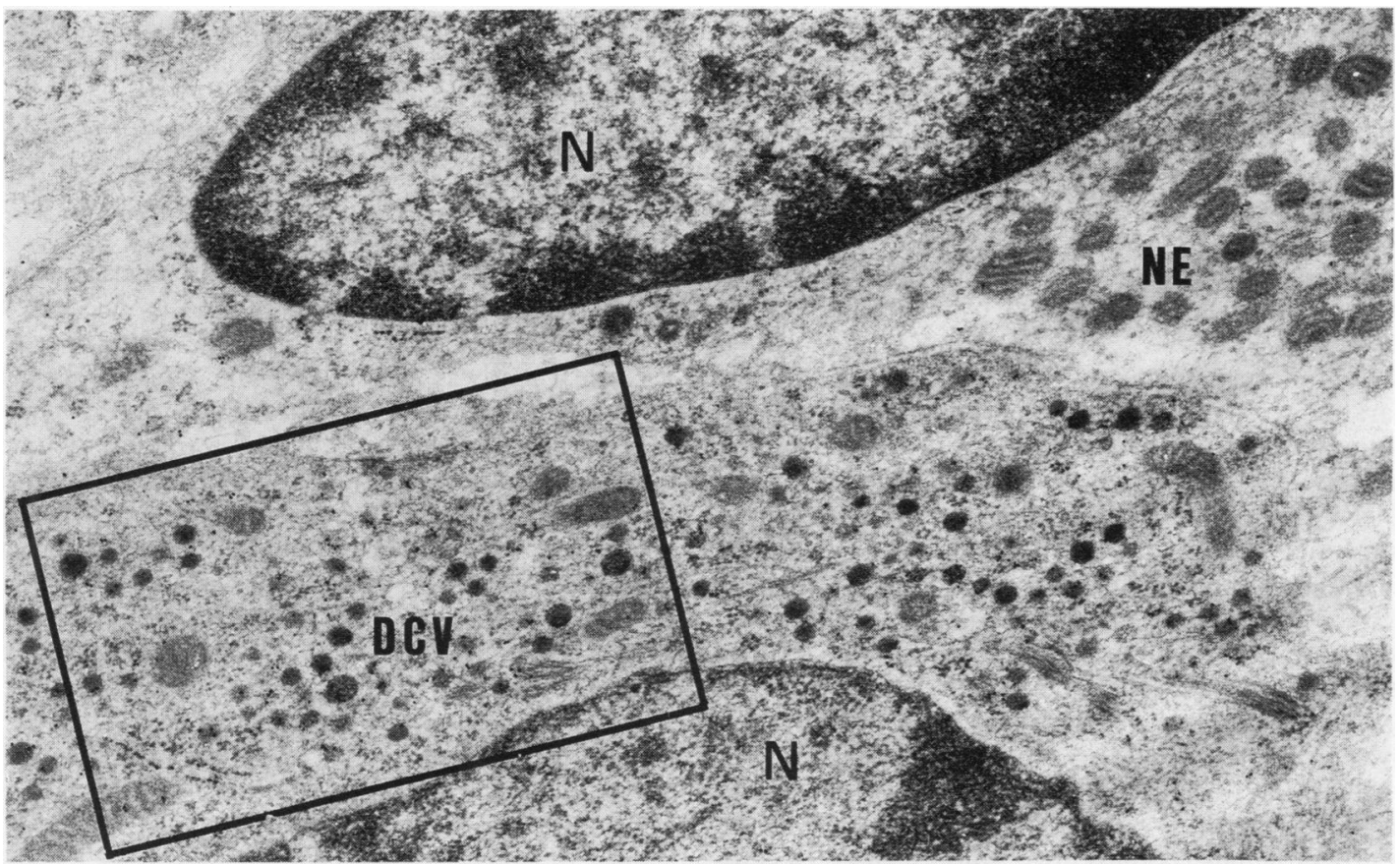

Fig 7 Neuroepithelial body immunostained for calcitonin gene related peptide. This low power micrograph reveals a cytoplasmic area containing dense cored vesicles, whose gold labelling is just visible at this magnification. The morphologically afferent nerve ending (NE) shows no labelling. N: nucleus. Uranyl acetate and lead citrate stain.

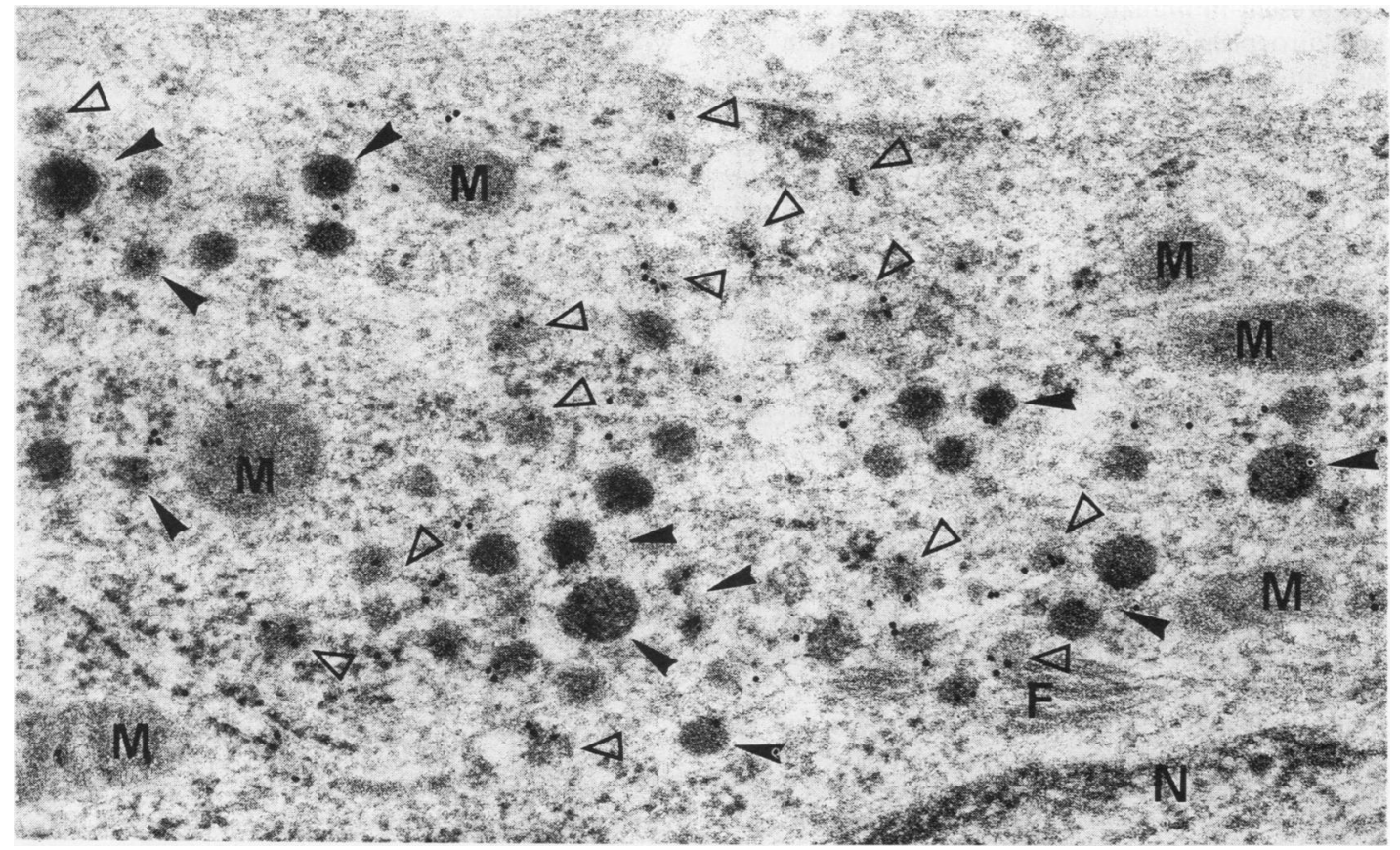

Fig 8 Enlargement of the framed area on figure 7, revealing dense cored vesicles of varying size and density. Dense cored vesicles with dark core (arrowheads) as well as those with paler core (open arrowheads) show specific CGRP immunoreactivity. A few gold particles are also visible over the cytoplasm and mitochondria. The latter are considered to correspond to non-specific background staining. N: nucleus; $M$ : mitochondria; F: filaments. 
reactive calcitonin gene related peptide is widely distributed in nerve fibres surrounding bronchi, bronchioli, and blood vessels, and in neuroendocrine cells and neuroepithelial bodies throughout the respiratory tract and alveolar epithelium. The peptide is also detectable by immunogold staining in the dense cored vesicles of neuroepithelial bodies in non-osmicated tissue. Rat and human CGRP are homologous in structure and can be recognised by heterologous antisera. ${ }^{10-12}$

Immunoreactive nerve fibres were not detected in paraffin sections, probably because of the reduced immunoreactivity of peptides in nerves of tissue processed at higher temperature. ${ }^{19}$ The absence of CGRP immunoreactivity of nerves in epoxy resin embedded and heat cured tissue could be explained by an increased sensitivity to heat of peptides in nerves, ${ }^{19}$ but it is also possible that no nerves containing the peptide were present in the sections studied. In this investigation the deleterious effects of osmium on immunoreactivity could not be reversed by pretreatment with sodium metaperiodate.

Since Lauweryns and Liebens first demonstrated the presence of a polypeptide substance in rabbit neuroepithelial bodies by fluorescence spectography, ${ }^{20}$ several polypeptides have been identified in human and animal lungs. Bombesin was the first peptide to be detected in human neuroendocrine cells and neuroepithelial bodies. ${ }^{21}$ Later, calcitonin was shown to be present in human and rat neuroendocrine cells and neuroepithelial bodies ${ }^{1622}$; leu-enkephalin was found in human neuroendocrine cells but not in neuroepithelial bodies. ${ }^{22}$ In addition to peptides, the indoleamine serotonin has been reported in neuroendocrine cells and neuroepithelial bodies of man, rabbit, and pig. ${ }^{23} 24$ The uptake of amines and amine precursors and the production of peptides support the inclusion of neuroendocrine cells and neuroepithelial bodies in the APUD system. Although these structures share common characteristics, neuroepithelial bodies appear to differ from neuroendocrine cells not only in peptide content but also as regards their cellular architecture, their more obvious innervation, and their response to experimental stimuli. ${ }^{25}$

Calcitonin gene related peptide has a wide distribution in the central and peripheral nervous system. Rosenfeld et al $^{1}$ reported specific CGRP immunostaining in neuronal systems known to subserve sensory, integrative, and motor functions. It is also found in the trigeminal ganglion and spinal sensory ganglia and their terminals in the brainstem and spinal cord, in sensory and motor nerves in the palate, ${ }^{7}$ and in neurones of the gastrointestinal tract, often associated with vascular smooth muscle. ${ }^{4}$ It is a potent dilator of pial and peripheral vessels in various animal species, ${ }^{6}$ suggesting that it has a vasoactive function. CGRP immunoreactivity has also been detected in the adrenal medulla ${ }^{1}$ and in the islets of Langerhans. $^{8}$

The presence of this peptide in the nerves of the lung and in neuroendocrine cells and neuroepithelial bodies suggest that it may exert its influence by either endocrine or paracrine pathways: it may, by diffusion, affect the tone of capillaries, whereas mucus production or bronchial smooth muscle tone may be influenced by paracrine secretion. A third or neurosecretory pathway is also possible: CGRP has been detected in the dense cored vesicles of the neuroepithelial body, which in the rabbit are mainly innervated by sensory neurones whose cell bodies lie in the nodose ganglion. ${ }^{26} \mathrm{~A}$ neurotransmitter or neuroregulatory or modulatory role therefore cannot be excluded. Moreover, recent work has indicated that in rabbits neuroepithelial bodies may serve as intrapulmonary chemoreceptors sensitive to hypoxia and modulated by the central nervous system. ${ }^{25-27}$ Further investigations, however, will be required to determine precisely which physiological actions are subserved by this newly identified intrapulmonary peptide.

This study was supported by a grant from the Fonds voor Geneeskundig Wetenschappelijk Onderzoek, Belgium. The authors wish to thank C Armee, R Renwart, E Swinnen, and MR Van Hamme for technical help; A Van Dormael for the photographic work; and G Bruyninckx for secretarial assistance.

\section{References}

1 Rosenfeld MG, Mermod J-J, Amara SR, et al. Production of a novel neuropeptide encoded by the calcitonin gene via tissue-specific RNA processing. Nature 1983;304:129-35.

2 Sabate MI, Stolarsky LS, Polak JM, et al. Regulation of neuroendocrine gene expression by alternative RNA processing. Colocalization of calcitonin and calcitonin gene-related peptide in thyroid C-cells. $J$ Biol Chem 1985;260:2589-92.

3 Sikri KL, Varndell IM, Hamid QA; et al. Medullary carcinoma of the thyroid: an immunocytochemical study of 25 cases using eight separate markers. Cancer 1985;56:2481-91.

4 Clague JR, Sternini C, Brecha NC. Localization of calcitonin gene-related peptide-like immunoreactivity in neurons of the rat gastrointestinal tract. Neuroscience Letters 1985;56:63-8.

5 Gibson SJ, Polak JM, Bloom SR, et al. Calcitonin gene- $\stackrel{\oplus}{+}$ related peptide immunoreactivity in the spinal cord of $T$ man and of eight other species. J Neurosci 1985;4: 3101-11.

6 Hanko J, Hardebo JE, Kåhrström J, Owman C, Sundler $F$. Calcitonin gene-related peptide is present in mammalian cerebrovascular nerve fibers and dilates pial 
and peripheral arteries. Neuroscience Letters 1985; 57:91-5.

7 Rodrigo J, Polak JM, Terenghi G, et al. Calcitonin generelated peptide (CGRP)-immunoreactive sensory and motor nerves of the mammalian palate. Histochemistry 1985;85:67-74.

8 Seifert H, Sawchenko P, Chesnut J, Rivier J, Vale W, Pandol SJ. Receptor for calcitonin gene-related peptide: binding to exocrine pancreas mediates biological actions. Am J Physiol 1985;249:G147-51.

9 Mason RT, Peterfreund RA, Sawchenko PE, Corrigan AZ, Rivier JE, Vale WW. Release of the predicted calcitonin gene-related peptide from cultured rat trigeminal ganglion cells. Nature 1984;308:653-5.

10 Morris HR, Panico M, Etienne T, Tippins J, Girgis SI, MacIntyre I. Isolation and characterisation of human calcitonin gene-related peptide. Nature 1984;308: 776-8.

11 Höppener JWM, Steenbergh PH, Zandberg J, et al. The second human calcitonin/CGRP gene is located on chromosome 11. Hum Genet 1985;70:259-63.

12 Amara SG, Arriza JL, Leff SE, Swanson LW, Evans RM, Rosenfeld MG. Expression in brain of a messenger RNA encoding a novel neuropeptide homologous to calcitonin gene-related peptide. Science 1985; 229:1094-7.

13 Lauweryns JM, Peuskens JC. Neuro-epithelial bodies (neuroreceptor or secretory organs?) in human infant bronchial and bronchiolar epithelium. Anat Rec 1972;172:471-82.

14 Lauweryns JM, Cokelaere M, Theunynck P. Neuroepithelial bodies in the respiratory mucosa of various mammals: a light optical, histochemical and ultrastructural investigation. Z Zellforsch 1972;135:569-92.

15 Wasano K. Neuroepithelial bodies in the lung of the rat and the mouse. Arch Histol Jpn 1977;40(suppl): 207-19.

16 Gosney JR, Sissons MCJ. Widespread distribution of bronchopulmonary endocrine cells immunoreactive for calcitonin in the lung of the normal adult rat. Thorax 1985;40:194-8.

17 Varndell IM, Tapia FJ, Probert L, et al. Immunogold staining procedure for the localization of regulatory peptides. Peptides 1982;3:259-72.

18 Bendayan M, Zollinger M. Ultrastructural localization of antigenic sites on osmium-fixed tissues applying the protein A-gold technique. J Histochem Cytochem 1983;31:101-3.

19 van Leeuwen F. Specific immunocytochemical localization of neuropeptides: a utopian goal? In: Bullock GR, Petrusz $\mathrm{P}$, eds. Techniques in immunocytochemistry. Vol 1. London: Academic Press, 1982:283-99.

20 Lauweryns JM, Liebens M. Microspectrography of formaldehyde and fluorescamine-induced fluorescence in rabbit pulmonary neuroepithelial bodies: demonstration of a new, probably polypeptide intracytoplasmic substance. Experientia 1977;33:1510-1.

21 Wharton J, Polak JM, Bloom SR, et al. Bombesin-like immunoreactivity in the lung. Nature 1978;273: 769-70.

22 Cutz E, Chan W, Track NS. Bombesin, calcitonin and leu-enkephalin immunoreactivity in endocrine cells of human lung. Experientia 1981;37:765-7.

23 Lauweryns JM, de Bock V, Verhofstad AAJ, Steinbusch HWM. Immunohistochemical localization of serotonin in intrapulmonary neuroepithelial bodies. Cell Tissue Res 1982;226:215-23.

24 Lauweryns JM, Van Ranst L, Verhofstad AAJ. Ultrastructural localization of serotonin in the intrapulmonary neuroepithelial bodies of neonatal rabbits by use of immunoelectron microscopy. Cell Tissue Res 1986;243:455-9.

25 Lauweryns JM, Cokelaere M, Deleersnyder M, Liebens $M$. Intrapulmonary neuroepithelial bodies in newborn rabbits. Influence of hypoxia, hyperoxia, nicotine, L-dopa and 5-HTP. Cell Tissue Res 1977;182:425-40.

26 Lauweryns JM, Van Lommel AT, Dom RJ. Innervation of rabbit intrapulmonary neuroepithelial bodies: quantitatve and qualitative ultrastructural study after vagotomy. J Neurol Sci 1985;67:81-92.

27 Lauweryns JM, Van Lommel A. Morphometric analysis of hypoxia-induced synaptic activity in intrapulmonary neuroepithelial bodies. Cell Tissue Res 1982;226:201-14. 